Н.В. Караєва

Національний технічний університет Украйни «КПІ імені Ігоря Сікорського», Київ

\title{
МЕТОДОЛОГІЧНІ АСПЕКТИ ТА ПРОГРАМНІ ЗАСОБИ ОЦІНКИ РИЗИКУ ЗДОРОВ'Ю НАСЕЛЕННЯ ПРИ НЕСПРИЯТЛИВОМУ ВПЛИВІ ФАКТОРІВ НАВКОЛИШНЬОГО СЕРЕДОВИЩА
}

\begin{abstract}
Доведено необхідність вдосконалення нормативно-методичного забезпечення оцінки ризику здоров'ю населення при несприятливому впливі факторів навколишнього середовища як базової умови функціонування ефективного механізму управління екологічною безпекою України. Визначено, щяо в базовій схемі оцінки ризику здоров'ю найбільш дискусійним є питання, щодо використання тих чи інших моделей оцінки залежності "доза-відгук", зокрема: лінійної моделі; лінійно-експоненціальної моделі; порогової моделі та моделі індивідуальних порогів дії. Досліджено світовий та вітчизняний досвід їх використання в залежності від типу задач та програмні засоби їх розрахунку.
\end{abstract}

Ключові слова: екологічна безпека, ризик здоров 'ю,потенційний ризик, очінка залежності "доза-відгук".

\section{Вступ}

Постановка проблеми. Сучасна теорія ризику як механізм управління екологічною безпекою базується на трьох взаємопов'язаних складових елементах:

1) системі аналізу та оцінці ризику;

2) системі управління ризиком;

3) системі інформування про ризик.

Метою аналізу й оцінки всіх видів ризику, як правило, є виявлення та ідентифікація джерел техногенно-екологічної небезпеки з установленням зв'язків між ними, а також оцінка можливого впливу зазначених джерел на характер та розміри збитку, який може бути заподіяно населенню, навколишньому середовищу, господарським й іншим об'єктам. Аналіз ризику надає основу для визначення ступеня і характеристики техногенно-екологічного ризику.

Система управління екологічним ризиком передбачає впровадження найбільш ефективних заходів щодо мінімізації ризиків економічних, екологічних та соціальних втрат об'єктів різного народногосподарського рівня і всього суспільства в цілому, обумовлених погіршенням якості навколишнього природнього середовища [1, с. 86] .

Інформування про ризик - це процес розповсюдження результатів визначення ступеня ризику для здоров'я людини і рішень щодо його контролю [2].

Специфікою процедури аналізу ризику для здоров'я населення, обумовлених погіршенням якості навколишнього середовища $є$ реалізація етапу оцінки залежності "дози-ефект" (відношення "дозивідгук"), тобто ймовірностей прояву небажаних для здоров'я ефектів при визначених рівнях впливу забруднювачів. Оцінка ймовірностей прояву небажаних для здоров'я реальних чи потенційних ефектів в результаті забруднення навколишнього природнього середовища є досить складним завданням.

Аналіз останніх досліджень і публікацій. Концепція оцінки ризику для здоров'я населення практично у всіх країнах світу і міжнародних організаціях розглядається як головний механізм розробки та прийняття управлінських рішень на всіх рівнях ієрархії щодо забезпечення екологічної безпеки як детермінанти сталого розвитку. В роботі [3] наведено перелік міжнародних інформаційних баз даних, що використовуються при оцінці ризику для здоров'я населення, зокрема: база токсикологічних даних Канадського центру з професійної безпеки і здоров'я (CCOHS) [4], електрона колекція карт безпеки Вермонтського університеті (Vermont SIRI MSDS Collection) [5], необхідна інформація з токсичної дії інгредієнтів Національного інституту США 3 професійної безпеки і здоров'я (NIOSH homepage) [6], інформаційна система Міністерства енергетики США (Risk Assessment Information System (RAIS)) [7] та ін. Крім того, інформаційно-моделююча система MEPAS застосовується в США та інших країнах світу у галузі промислової та екологічної безпеки при планування раціональних дій та заходів щодо профілактики та відновлення стану навколишнього середовища та зменшення негативного впливу на здоров'я людей [8]. Загалом, як показано нами у попередній роботі [9], в міжнародній практиці використовується значна кількість комп'ютерних систем і програмних засобів в різнопланових задачах екологічної безпеки, але лише деякі 3 них призначені для оцінки і моделювання ризику для здоров'я населення.

В Україні ухвалено низку нормативно-правових актів, які зобов' язують наглядові органи оцінювати за рівнем ризику прийнятність і надмірну небезпеку видів діяльності, пов'язаних з можливими аварійними ситуаціями, що мають несприятливі наслідки для здоров'я населення і навколишнього середовища. Це, зокрема, Закон України "Про об’єкти підвищеної небезпеки" [10] та постанова Кабінету Міністрів України "Про ідентифікацію та декларування безпеки об'єкти підвищеної небезпеки" [11]. 3 метою виконання Закон України "Про об’ єкти підвищеної небез- 
пеки" Міністерство праці і соціальної політики розробило Методику визначення ризиків та їх прийнятних рівнів для декларування безпеки об'єктів підвищеної небезпеки [12]. Але в Методиці не наведено математичних моделей і методів розрахунку ризиків, що ускладнює іії використання на практиці.

В 2019 році в Україні розроблено зміни та доповнення до ДБН А.2.2-1-2003 щодо оцінки ризику впливу планованої діяльності на навколишнє середовище [13], де представлена методика оцінки впливу промислової діяльності на здоров'я населення та рівня соціального ризику при забрудненні лише атмосферного повітря. Цей нормативний документ містить спрощений варіант розрахунку ризику розвитку канцерогенних та неканцерогенних ефектів, що наведено в Методичних рекомендації (MP 2.2.12-142-2007) "Оцінка ризику для здоров'я населення від забруднення атмосферного повітря" [14]. Саме тому, в Україні для проведення експертних процедур оцінки впливів на навколишне середовище (ОВНС) використовується окрема утиліта "Показник ризику" [15] ліцензованого програмного продукту "ЕОЛ 2000[h]", що дає змогу здійснити оцінку ризиків запланованої діяльності та соціальних ризиків лише за фактором атмосферного повітря.

Слід зазначити, що основою розробки МР 2.2.12142-2007 слугували підходи Американського Агентства 3 охорони навколишнього середовища (United States Environmental Protection Agency - EPA US) [16] i Pociï $[17,18]$, в яких широко представлені методологічні основи оцінки реального ризику здоров'я населення, пов'язаного з хімічним забрудненням основних компонентів навколишнього середовища.

Закордонний досвід оцінки потенціального ризику здоров'я населення в результаті хімічного забруднення різних компонентів навколишнього середовища наведено в роботах [19-21].

Вищенаведена проблематика реалізації концепції оцінки ризику для здоров’я населення в Україні як механізму управління екологічною безпекою зумовлює актуальність дослідження.

Мета роботи - на основі аналізу міжнародного досвіду розробити методологічні основи оцінки ризику здоров'ю населення при несприятливому впливі факторів навколишнього середовища.

\section{Виклад основного матеріалу}

Згідно МР 2.2.12-142-2007 повна, або базова, схема оцінки ризику здоров'ю передбачає проведення чотирьох взаємопов'язаних етапів: 1) ідентифікацію небезпеки; 2) оцінку експозиції; 3) характеристику небезпеки (оцінку залежності "дозавідгук"); 4) характеристику ризику.

Головним завданням першого етапу є відбір пріоритетних, індикаторних хімічних речовин, вивчення яких дозволить 3 достатньою точністю охарактеризувати рівні ризику порушення стану здоров'я населення та джерела його виникнення. В результаті здійснення першого етапу оцінки ризику повинні бути отримані відповіді на питання: які фактори, що присутні в навколишньому середовищі досліджуваного району, можуть викликати несприятливі для здоров'я ефекти; який несприятливий вплив можуть надати ці чинники; яка нова інформація необхідна для судження про небезпеку цих факторів.

Оцінка експозиції передбачає визначення шляху розповсюдження у навколишньому середовищі і впливу на організм забруднюючої сполуки, вивчення iii концентрацій, установлення терміну дії і загальної тривалості впливу, оцінки чисельності популяції, яка знаходиться або вірогідно може знаходитись під впливом шкідливого чинника. Для того щоб оцінити вплив шкідливих чинників на здоров'я людини потрібна інформація про взаємодію між ними, тобто визначення зв'язку між експозицією шкідливим фактором і ефектом на здоров'я, який може проявлятися іноді і не відразу, а через значний час.

Найбільші дискусії виникають при реалізації третього етапу - оцінки залежності "доза-відгук". На цьому етапі встановлюються або прогнозуються зв'язки між дозою або концентрацією шкідливого фактору і відносним числом індивідуумів з кількісно визначеним прояву несприятливого для здоров'я ефекту. Результати дослідження робіт $[20,22,23]$ свідчать, що в залежності від типу задач в світовій практиці використовують чотири основних математичних моделей оцінки залежності "доза-відгук".

1. Лінійна модель має вигляд:

$$
\text { Risk }=\mathrm{UR} \cdot \mathrm{C} \cdot \mathrm{t},
$$

де Risk - ризик виникнення несприятливого ефекту, який визначається як імовірність виникнення цього ефекту при заданих умовах; $\mathrm{C}$ - реальна концентрація (або доза) речовини, що надає вплив за час t; UR одиниця ризику, що визначається як фактор пропорції зростання ризику в залежності від величини діючої концентрації (дози). Як правило визначається експертними методами при статистичному аналізі експериментального або медико-статистичного матеріалу, отриманого різними авторами в порівнянних ситуаціях.

2. Лінійно-експоненціальна модель має вигляд:

$$
\text { Risk }=1-\exp (-U R \cdot C \cdot t) \text {. }
$$

3. Порогова модель передбачає наявність порогу, нижче якого фактор практично не діє [20]:

$$
\text { Risk }=\mathrm{H}(\mathrm{C}-\mathrm{C} \Pi) \text {, }
$$

де $\mathrm{H}-$ функція Гевісайда $(\mathrm{H}(\mathrm{x})=0$ при $\mathrm{x}<0$ i $\mathrm{H}(\mathrm{x})=1$ при $\mathrm{x}>0$ ); $\mathrm{C}$ - концентрація впливу; Сп - порогова концентрація.

4. Модель індивідуальних порогів дії (нормально-імовірнісний розподіл частоти ефектів, пробітаналіз) застосовується для визначення гострої токсичності хімічних речовин [20]:

$$
\text { Risk }=\left(1 / \sqrt{(2 \pi)} \cdot \int_{-\infty}^{(a+b \cdot \lg (C))} e^{-t / 2} \cdot d t,\right.
$$

де $\mathrm{C}$ - концентрація впливу; a i b - емпіричні коефіцієнти. Ця модель використовується, головним чином, при розрахунку потенційного ризику негайних неканцерогенних ефектів. 
Використання тих чи інших моделей оцінки залежить, в першу чергу, який вид ризику здоров'ю ми розраховуємо - реальний чи потенційний. Також оцінка залежності "доза-відгук" принципово відрізняється для канцерогенів і неканцерогенів. Так, на думку російських науковців [23] для оцінки канцерогенного ризику застосовується лінійна безпорогова модель, яка використовує величини потенціалів канцерогенного ризику, які є індивідуальною характеристикою кожної речовини. Для розрахунку ризику неканцерогенних хронічних ефектів доцільно використовувати експоненціальну безпорогову модель, що дає оцінку ймовірності збільшення первинної захворюваності популяції у відповідь на тривалий вплив неканцерогена.

Вітчизняне нормативно-методичне забезпечення спрямовано на розрахунок лише реального ризику розвитку канцерогенних та неканцерогенних ефектів 3 використанням лінійних моделей оцінки залежності "доза-відгук". У загальному визначені реальний ризик це кількісне вираження шкоди суспільному здоров'ю, пов'язаної із забрудненням навколишнього середовища, у величинах додаткових випадків захворювань, смерті та ін. Звичайно, використовується при оцінці існуючих ситуацій чи ретроспективних досліджень. Так, наприклад, у відповідності МР 2.2.12-142-2007 розрахунок індивідуального канцерогенного ризику $(C R)$ від забруднення атмосферного повітря здійснюють за формулою:

$$
\mathrm{CR}=\mathrm{SF} \cdot \mathrm{LADD} \text {, }
$$

де $\mathrm{CR}$ - імовірність занедужати раком, безвимірна величина (звичайно виражається в одиницях 1:1000000); SF - фактор нахилу, тобто імовірність одержання ракового захворювання у випадку прийому одиничної дози LADD (Lifetime Average Daily Dose), $\left.(1 / \text { мг/(кг } \times \text { доба), ((мг/(кг × доба })^{-1}\right) ;$ LADD середня добова доза протягом життя, мг/(кг × доба).

Розрахунок популяційного річного ризику (PCRa) від забруднення атмосферного повітря здійснюють за формулою:

$$
\mathrm{PCRa}=\sum\left(\mathrm{C}_{\mathrm{i}} \cdot \mathrm{UR}_{\mathrm{i}}\right) \cdot \mathrm{POP} / 70,
$$

де $\mathrm{C}_{\mathrm{i}}$ - середня річна концентрація i-тої речовини; POP - чисельність популяції, що зазнає впливу (чол.), $\mathrm{UR}_{\mathrm{i}}$ - одиничний ризик протягом життя (70 років).

Для характеристики ризику розвитку неканцерогенних ефектів передбачається визначення коефіцієнту небезпеки для окремих забруднюючих речовин $\left(H Q_{i}\right)$ і розрахунку індексу небезпеки за формулою:

$$
\mathrm{HI}=\sum \mathrm{HQ}_{\mathrm{i}} \text {. }
$$

В той же час, в Інструкції 2.1.6.11-9-29-2004 Мiністерства охорони здоров'я республіки Білорусь "Оцінка ризику для здоров'я населення від впливу хімічних речовин, що забруднюють атмосферне повітря" [21] при відносно високих рівнях впливу канцерогену (скринінговий рівень ризику більш 0,01) розрахунок потенційного канцерогенного ризику пропонується здійснюється за експоненціальною моделлю:

$$
\mathrm{CR}=1-\exp \left(-\mathrm{SF}_{\mathrm{i}} \cdot \mathrm{LADD}\right)
$$

На відміну від вітчизняного підходу для оцінки ризику розвитку неканцерогенних ефектів, крім вищезазначених показників, що характеризують рівень реального ризику, в російській практиці здійснюється розрахунок потенціального ризику [19, 20, 23]. В республіки Білорусь оцінка потенційного ризику негайної (рефлекторного) дії та тривалого (хронічного) впливу регламентована Інструкцією 2.1.6.11-9-292004 [21]. Впроваджена у вітчизняну практику методику розрахунку потенційного ризику розвитку неканцерогенних ефектів успішно може бути використана для медико-екологічної оцінки якості навколишнього середовища, в тому числі і для перспективних цілей. У 2005 році про актуальність і переваги застосування методики оцінки потенційного ризику здоров'ю населення України вітчизняні науковців відмічали в роботі [24]. На думку авторів методика дозволяє рангувати рівні забруднення за кількома ступенями - від припустимої (чи прийнятної) до надзвичайно небезпечної. Як ефект оцінюється не ризик появи додаткових випадків захворювань, а імовірність рефлекторних реакцій (відчуття роздратування, неприємного запаху тощо) чи ефектів психологічного дискомфорту, що також розцінюється як факт порушення здоров'я [24,c.162]. У загальному визначені потенційний ризик це ризик виникнення несприятливого для людини ефекту, що визначається як можливість виникнення цього ефекту при заданих умовах. Виділяють три типи потенційного ризику:

1) ризик негайних ефектів, що проявляються безпосередньо в момент впливу (неприємні запахи, роздратовуючи ефекти, різноманітні фізіологічні реакції, загострення хронічних захворювань та ін., а при значних концентраціях - гострі отруєння);

2) ризик тривалого (хронічного) впливу, що проявляється при накопиченні достатньої для цього дози, у рості неспецифічної патології, зниженні імунного статусу і т.п.;

3) ризик специфічної дії, що проявляється у виникненні специфічних захворювань чи канцерогенних, ембріотоксичних та інших подібних ефектів.

Оцінки залежності "доза-відгук" в задачах розрахунку потенційного ризику для здоров'я населення заснована на логарифмічній залежності від рівнів впливу забруднюючих речовин і дозволяє адекватно інтегрувати їх. Наведемо основні розрахункові модулі потенційного ризику, що обчислюється окремо залежно від якості атмосферного повітря, питної води, водних об'єктів, грунту, продуктів харчування та рівня шуму (опис модулів цитуються за $[19,21$, $24,25]$. В результаті забруднення атмосферного повітря ризик прояву негайних токсичних ефектів оцінюється для чотирьох класів небезпеки забруднюючих речовин у пробітах ( Prob ) за формулами [19]:

1 клас Prob $=-9,15+11,66 \cdot \lg ($ С / ГДКм.p $)$,

2 клас Prob $=-5,51+7,49 \cdot \lg ($ С $/$ ГДКм.p $)$,

3 клас Prob $=-2,35+3,73 \cdot \lg ($ С $/$ ГДКм.p $)$,

4 клас Prob $=-1,41+2,33 \cdot \lg ($ С $/$ ГДК м.p $)$, 
де C - концентрація забруднюючої речовини; ГДК м.p. - максимальні разові ГДК. Відповідність "пробітів" і ймовірності ефекту (Risk) пов'язані табличним інтегралом $[21,25]$ :

$$
\text { Risk }=\left(1 / \sqrt{(2 \pi)} \int_{-\infty}^{\text {Prob }} e^{t / 2} d t .\right.
$$

Для практичного перетворення Prob в Risk можна використовувати спеціальну таблицю або вбудовані функції спеціалізованих пакетів програм. Так, наприклад, загальновідомий табличний процеcop Excel, який $є$ складовою частиною продуктів cepiï Microsoft Office, для цієї мети пропонує вбудовану функцію нормального імовірнісного розподілу.

Оцінка потенційного ризику здоров'ю населення при хронічному впливі забруднення атмосфери розраховується за експоненціальною моделлю [21]:

$$
\text { Risk }=1-\exp \left(\ln (0,84) \cdot(\mathrm{C} / \text { ГДК } \text { сд }) \text { b/K }{ }_{3}\right),
$$

де $\mathrm{C}$ - концентрація речовини, що робить вплив за заданий період часу; ГДК нично допустима концентрація; $K_{3}$ - коефіцієнт запасу (значення змінюються в залежності від класу небезпеки речовини: 1 -й клас $-7,5 ; 2$-й клас $-6,0$; 3-й клас - 4,5; 4-й клас - 3 ); b - коефіцієнт, що дозволяє оцінювати ізоефективні ефекти домішок різних класів небезпеки: 1-й клас $-2,35$; 2-й клас 1,28; 3-й клас - 1,0 і 4-й клас - 0,87.

Оцінка потенційного ризику здоров'ю населення в залежності від якості питної води визначається окремо за органолептичними, епідеміологічними i токсикологічними показниками якості води. Ризик за водневим показником визначається за формулами:

$$
\begin{aligned}
& \text { Prob }=4-\mathrm{pH} \quad \text { при } \mathrm{pH} \leq 7, \\
& \text { Prob }=-11-\mathrm{pH} \text { при } \mathrm{pH}>7 .
\end{aligned}
$$

Ризик за іншими показниками, нормованим за їхнім впливом на органолептичні якості води, визначається з використанням рівняння Prob -аналізу:

$$
\text { Prob }=-2+3,32 \cdot \lg (\mathrm{C} / \text { ГДК }) .
$$

Потенційний ризик токсикологічної небезпеки питної води визначається за експоненціальною моделлю:

$$
\text { Risk }=1-\exp ((\ln (\mathrm{OSF}) / \mathrm{C} . \mathrm{liT}) \cdot \mathrm{LADD}),
$$

де C.liт - порогові концентрації, пов'язані $з$ максимальними недіючими ГДК (для речовин, регламентованих за токсикологічною ознакою) рівнянням:

$$
\text { C.liт }=\Gamma Д К \cdot K_{3},
$$

де $\mathrm{K}_{3}$ - коефіцієнт запасу, що приймається рівним 100 у речовин 3 вираженою імовірністю віддалених наслідків і 10 для інших речовин; LADD - середня щоденна концентрація (чи доза) речовини, що надходить в організм людини 3 питною водою на протязі їі життя та обчислюється за формулою:

$$
\mathrm{LADD}=\mathrm{CW} \cdot \mathrm{IR} \cdot \mathrm{EF} \cdot(\mathrm{ED} / \mathrm{BW}) \cdot \mathrm{AT},
$$

де CW - концентрація у воді (мг/л); IR - рівень споживання (л/добу); $\mathrm{EF}$ - частка експозиції (днів/рік); ED - тривалість експозиції (років); BW вага тіла (кг); АТ - час усереднення (період, за який усереднюється експозиція). Ризик за показником забарвленості визначається відповідно до рівняння:

$$
\text { Prob }=-3,33+0,067\left(Ц-\Phi_{\text {он }}+20\right),
$$

де $\Phi_{\text {он }}-$ природна забарвленість води, отримана за даними багаторічних спостережень і характерна для даного сезону; Ц - забарвленість води (у градусах забарвленості).

При оцінці ризику за показником природного запаху і присмаку води використовується формула:

$$
\text { Prob }=-1+3,32 \cdot \lg (\text { Бали } / 2,5) .
$$

Ризик за іншими показниками, нормованим відповідно до їхнього впливу на органолептичні властивості води, визначається на основі рівняння:

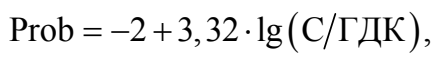

де $\mathrm{C}$ - концентрація речовини у водному об'єкті; ГДК - норматив для водних об'єктів рекреаційного водокористування. Потенційний ризик здоров'ю населення в залежності від якості грунту обчислюється за лінійно-експоненціальною моделлю:

$$
\text { Risk }=1-\exp (-\mathrm{UR} \times \mathrm{LADD}),
$$

де UR - одиниця ризику, визначається як чинник пропорції росту ризику в залежності від значення діючої концентрації (дози) речовини; LADD - середня щоденна доза речовини (мг/кг-добу),

$\mathrm{LADD}=\mathrm{CS} \cdot \mathrm{IR} \cdot \mathrm{CF} \cdot \mathrm{FI} \cdot \mathrm{EF} \cdot(\mathrm{ED} / \mathrm{BW}) \cdot \mathrm{AT}$,

де CS - концентрація речовини в воді (мг/кг); IR рівень споживання (мг грунту/добу - 200 мг/добу для дітей 1-6 років та 100 мг/день для дорослих); CF - коефіцієнт(10-6 кг/мг); FI - частка речовини, що проникає через шкіру; EF - частка експозиції (днів/рік); ED - тривалість експозиції (років); BW вага тіла (кг); АТ - час усереднення (період, за який усереднюється експозиція).

Потенційний ризик здоров’ю населення в залежності від якості продуктів розраховується як

$$
\text { Risk }=1-\exp (-\mathrm{UR} \times \mathrm{LADD}) \text {, }
$$

де UR - одиниця ризику, визначається як чинник пропорції росту ризику в залежності від визначення діючої концентрації (дози) речовини; LADD (мг/кгдобу) обчислюється за формулою:

$\mathrm{LADD}=\mathrm{CF} \times \mathrm{IR} / \mathrm{BW} \times \mathrm{AT}$, де $\mathrm{CF}$ - концентрація шкідливої речовини в їжі (мг/кг); IR - рівень споживання (кг сирої ваги в добу); BW - вага тіла (кг).

Потенційний ризик неспецифічних ефектів при постійному впливі шуму обчислюється як

$$
\text { Prob }=-4,5551+0,0853 \cdot \ell_{\text {екв}},
$$

де $\ell_{\text {екв }}$ - еквівалентний рівень шуму в дб (А).

Ризик розвитку специфічної приглухуватості при постійному впливі шуму розраховується як

$$
\text { Prob }=-6,771+0,0704 \cdot \ell_{\text {екв }} .
$$

При короткочасному впливі шуму до вищенаведених рівнянь потрібно поправку. У тому випад-

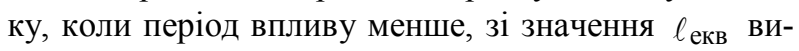
ключають виправлення на час дії протягом доби $\mathrm{L}_{1}$, що обчислюється за формулою: 


$$
\mathrm{L}_{1}=10 \cdot \lg \left(24 / \mathrm{T}_{1}\right),
$$

де $\mathrm{T}_{1}$ - середній час дії шуму протягом доби.

На етапі характеристики ризику проводиться оцінка комбінованої чи комплексної дії негативних чинників. Під комбінованою дією розуміється вплив декількох домішок, що надходять через один 3 компонентів навколишнього середовища (повітря, вода і т.д.). Комплексна дія - це вплив однієї чи декількох домішок, оцінюване через кілька факторів навколишнього середовища (повітря, вода чи ін.).

Для оцінки комбінованої та комплексної дії використовують два підходи:

1) при комбінованої дії декількох домішок, що володіють ефектом сумації, використовують метод розрахунку приведеної концентрації $\left(C_{n p}\right)$ :

$$
\mathrm{C}_{\text {пр }}=\mathrm{C}_{1}+\mathrm{C}_{2} \cdot \frac{\Gamma Д \mathrm{~K}_{1}}{\Gamma Д \mathrm{~K}_{2}}+\ldots+\mathrm{C}_{\mathrm{n}} \cdot \frac{\Gamma Д \mathrm{~K}_{1}}{\Gamma Д \mathrm{~K}_{\mathrm{n}}},
$$

де $\mathrm{C}_{1}, \mathrm{C}_{2}, \ldots, \mathrm{C}_{\mathrm{n}}$ - концентрації 1-ої, 2-ої, ..., n-ої домішок, ГДК $1, \ldots$, ГДК $\mathrm{n}$ - відповідно їх нормативи;

2) метод оцінки за правилом множення імовірностей, де як множник виступають не величини ризику здоров'ю, а значення, що характеризують імовірність його відсутності:

Risk $_{\text {сум }}=1-\left(1-\right.$ Risk $\left._{1}\right)\left(1-\right.$ Risk $\left._{2}\right)\left(1-\right.$ Risk $\left._{3}\right) \ldots\left(1-\right.$ Risk $\left._{n}\right)$, де $\operatorname{Risk}_{\text {сум }}$ - потенційний ризик комбінованого чи комплексного впливу домішок; Risk ${ }_{1}, \ldots$, Risk $_{\mathrm{n}}$ - потенційний ризик впливу кожної окремої домішки.

За даними [20] комбінований ризик появи несприятливих для здоров'я ефектів, розрахований за першим і другим підходах, дають абсолютно ідентичні результати.

При трактування отриманих величин потенційного ризику здоров'ю населення користуються ранговою шкалою, яку наведено в табл. 1.

Залежність ваги ефектів

\begin{tabular}{|c|c|}
\hline Вага ефектів & Risk \\
\hline Рівні мінімального ризику & $<0,1$ \\
\hline Граничні хронічні ефекти & $0,1-0,19$ \\
\hline Важкі хронічні ефекти & $0,2-0,59$ \\
\hline Важкі гості ефекти & $0,6-0,89$ \\
\hline Смертельні ефекти & $0,9-1,0$ \\
\hline
\end{tabular}

від величини ризику здоров'ю населення

\section{Висновки}

1. Проблемність функціонування ефективного механізму управління екологічною безпекою України лежить у площині невдосконаленого нормативнометодичного забезпечення оцінки екологічного ризику, зокрема, ризику здоров'ю населення при несприятливому впливі факторів навколишнього середовища.

2. Основними недоліками нормативно-методичного забезпечення $є$ такі: відсутність математичних моделей розрахунку ризиків у Методиці визначення ризиків та їх прийнятних рівнів для декларування безпеки об'єктів підвищеної небезпеки; в ДБН А.2.2-1-2003 і МР 2.2.12-142-2007 наведені методики оцінки впливу промислової діяльності на здоров'я населення та рівня соціального ризику лише при забрудненні атмосферного повітря. Крім того, вітчизняні методики спрямовані на оцінку лише реального канцерогенного і неканцерогенного ризику, при цьому в міжнародній практиці широко використовуються методики розрахунку потенційного ризику розвитку неканцерогенних ефектів.

3. Вищенаведені недоліки нормативно-методичного забезпечення унеможливлюють розробку і впровадження вітчизняних програмних засобів, призначених для всебічної оцінки і моделювання ризику для здоров'я населення при несприятливому впливі факторів навколишнього середовища. 3 метою реалізації аналітичного блоку системи в роботі наведено основні розрахункові модулі потенційного ризику, що обчислюється залежно від якості атмосферного повітря, питної води, водних об'єктів, грунту, продуктів харчування та рівня шуму.

4. Визначено, що в базовій схемі оцінки ризику здоров'ю найбільш дискусійним $є$ питання, щодо використання тих чи інших моделей оцінки залежності "доза-відгук". В залежності від типу задач в у міжнародній і вітчизняній практиці використовують чотири основних моделей оцінки залежності "дозавідгук": 1) лінійна модель; 2) лінійно-експоненціальна модель; 3) порогова модель; 4) модель індивідуальних порогів дії. Використання тих чи інших моделей оцінки залежить, в першу чергу, який вид ризику здоров'ю ми розраховуємо - реальний чи потенційний. Також оцінка залежності "доза-відгук" принципово відрізняється для канцерогенів і неканцерогенів.

\section{Список літератури}

1. Жарова Л.В. Макроекономічне регулювання природоохоронної діяльності : монографія / Л. В. Жарова. Суми: Університетська книга, 2012-296с.

2. Оиінка ризику для здоров'я населення від забруднення атмосферного повітря / МР 2.2.12-142-2007. Київ : МОЗ України, 2007. - 40 с.

3. Березуцький В.В. Небезпечні виробничі ризики та надійність / В.В. Березуиький, М.I. Адаменко - Харків : ФОП Панов А.М., 2016. - 385 c.

4. Canadian Centre for Occupational Health and Safety: Comprehensive, Practical occupational health and safety information on chemicals [Электронный ресурс]. - Режсим достуna: http://www.ccohs.ca/products/databases/cheminfo.html.

5. Vermont Safety Information Resources, Inc.: Chemical toxicity data: [Електроний ресурс]. - 2011. - Peжим доступу: http://hazard.com/msds/ (Вермонтский університет (Vermont SIRI MSDS Collection). Електрона колекиія карт безпеки. http://hazard.com/msds/index.html).

6. NIOSH: National Institute for Occupational Safety and Health: International chemical safety cards (ICSC): [Електроний ресурс]. - 2011. - Режим доступу: http://www.cdc.gov/niosh/ipcs/icstart.html.

7. United States Environmental Protection Agency: region 3 risk assessment: [Електроний ресурс]. - 2011. Режим доступy: http://www.epa.gov.

8. Попов О.О. Інформаційні системи для вирімення задач комплексного радіоекологічного моніторингу АЕC / О.О. Попов, А.В. Яичиин // Моделювання та інформачійні технології. - 2014. - Вип. 72. - С. 3-16. 
9. Караєва Н. В. Характеристика можливостей комп'ютерних систем і програмних засобів для економіко-екологічного аналізу господарської діяльності [Електронний ресурс] / Н. В. Караєва // Глобальні та національні проблеми економіки. - Грудень 2017. - № 14. - Режим docmyny: http://global-national.in.ua/issue-14-2016.

10. Закон України "Про об'єкти підвищеної небезпеки" від 18.01. 2001 р., № 2245-III [Електронний ресурс]. - Режсим docmyny: http://zakon3.rada.gov.ua/laws/show/2245-14.

11. Постанова Кабінету Міністрів України від 11 липня 2002 р. № 956 "Про ідентифікацію та декларування безпеки об'єктів підвищеної небезпеки" / Кабінет Міністрів Украӥни [Електронний ресурс] - Режим доступу : http://zakon4.rada.gov.ua/laws/show/956-2002-\%D0\%BF.

12. Наказ Міністерства праиі та соиіальної політики Украӥни від 04.12. 2002 р. № 637 "Про затвердження Методики визначення ризиків та їх прийнятих рівнів для декларування безпеки об'єктів підвищеної небезпеки" [Електронний ресурс] - Режим доступу : http://uainfo.biz/legal/basene/ua-cmelgt/index.htm.

13. ДБНА. 2.2-1-2003. Зміна № 1. Проектування. Склад $і$ зміст матеріалів оцінки впливів на навколишне середовище (ОВНС) при проектуванні і будівництві підприємств, будинків і споруд : Наказ Мінрегіонбуду України від 20.11.2009 p. № 524 та введені в дію 01.07.2010 p. - К. : ДП «Укрархбудінформ» Мінрегіонбуд, 2010. $10 \mathrm{c}$.

14. Методичні рекомендації МР 2.2.12-142-2007. Оиінка ризику для здоров'я населення від забруднення атмосферного повітря. Затв. Наказом МОЗ Украӥни від 13.04.07 № 184. - Київ, 2007. - 40 c.

15. Перелік програмних продуктів в галузі охорони атмосферного повітря [Електронний ресурс]. - Режим docmyny : http://www.menr.gov.ua/protection/protection3/ regulation/255-perelik-prohramnykh-produktiv-v-haluziokhorony-atmosfernohopovitria.

16. Integrated Risk Information System (IRIS) : [Електронний ресурс] / U. S. Environmental Protection Agency (EPA). - Режим доступy: https://www.epa.gov/iris.

17. Основы оченки риска для здоровья населения при воздействии химических веществ, загрязняюших окружаюшую среду /Г.Г.Онишенко, С.М.Новиков, Ю.А. Рахманин и др./ Под ред. Ю.А. Рахманина, Г.Г.Онищенко. M., 2002. $-408 c$.
18. Руководство по оченке риска для здоровья населения при воздействии химических веществ, загрязняющих окружаюшую среду/ Ю.А. Рахманин, С.М. Новиков, Т.А. Шашина и др. - М. : Федеральный центр госсанэпиднадзора Минздрава России, 2004.-143c.

19. Киселев А.В. Оиенка риска здоровью. Подходык к использованию в медико- экологических исследованиях и практике управления качеством окружающей среды: методич. пособие / А.В. Киселев, К.Б. Фридман. - СПб.: Межд. институт оценки риска здоровью, 1997. - 100 c.

20. Киселев А.В. Оиенка потенциального риска здоровью в системе гигиенического мониторинга при оценке качества окружающей среды [Электронный ресурс] Режим доступа : https://uzmzcge.by/files/news/risky.doc.

21. Инструкиия 2.1.6.11-9-29-2004 ГЭлектронный ресурс] / Министерства здравоохранения республики Беларусь "Оченка риска для здоровья населения от воздействия химических веществ, загрязняющих атмосферный воздух»-Режим доступа :

http://med.by/methods/pdf/2.1.6.11-9-29-2004.pdf.

22. Moghissi A.A., Narland R.E., Congel F.J. Eckerman K.F. Methodology for environmental human exposure and health risk assessmen // Dyn.Exposure and Hazard Assessment Toxic chem. Ann Arbor.,Michigan, USA, 1980, p. 471- 489.

23. Трифонова Т.А. Оценка и сравнительный анализ рисков для здоровья населения (на примере г. Владимир) / Трифонова Т.А., Ширкин Л.А. - Владимир: ВООО ВОИ ПУ «Pocm», 2010. $-80 \mathrm{c}$.

24. Гриценко А.В. Оиінка потенційного ризику здоров'ю населення Украӥни при несприятливому впливі факторів навколишнього середовища / А.В. Гриценко, О.В. Рибалова, Л.Ю. Ільченко // Коммунальное хозяйство городов. - Киев : Техніка, 2005. - Вып.63. Сер. Техн. науки. - С. $161-171$.

25. Методические рекомендачии МР 2.1.4.0032-11. Интегральная оценка питьевой воды централизованных систем водоснабжения по показателям химической безвредности: Методические рекомендации. - М. : ФБУЗ «Федеральный иентр гигиены и эпидемиологии» Роспотребнадзора, 2011. - 37 c.

Надійшла до редколегії 1.12.2017

Рецензент: д-р техн. наук, проф. О.І. Запорожець, Національний авіаційний університет, Київ.

\title{
МЕТОДОЛОГИЧЕСКИЕ АСПЕКТЫ И ПРОГРАММНЫЕ СРЕДСТВА ОЦЕНКИ РИСКА ЗДОРОВЬЮ НАСЕЛЕНИЯ ПРИ НЕБЛАГОПРИЯТНОМ ВОЗДЕЙСТВИИ ФАКТОРОВ ОКРУЖАЮЩЕЙ СРЕДЫ
}

\author{
Н.В. Караева
}

Доказана необходимость совершенствования нормативно-методического обеспечения оценки риска здоровью населения при неблагоприятном воздействии факторов окружающей среды как базового условия функиионирования эффективного механизма управления экологической безопасностью Украины. Определено, что в базовой схеме оценки риска здоровью наиболее дискуссионным является вопрос относительно использования тех или иных моделей оиенки зависимости "доза-отклик", в частности: линейной модели; линейно-экспоненциальной модели; пороговой модели и модели индивидуальных порогов действия. Исследован мировой и отечественный опыт их использования в зависимости от типа задач и программные средства их расчета.

Ключевые слова: экологическая безопасность, риск здоровью, потенциальный риск, оценка зависимости «доза-ответ".

\section{METHODOLOGICAL ASPECTS AND SOFTWARE TOOLS OF POPULATION HEALTH RISK ASSESSMENT UNDER NON-COMPREHENSIVE INFLUENCE OF FACTORS OF THE ENVIRONMENT}

\author{
N.V. Karaieva
}

The need to improve the regulatory and methodological support for risk-assessing to the health of the population with adverse effects of environmental factors as a basic condition for the functioning of an effective mechanism for managing environmental safety of Ukraine is proved. The most controversial topic in the basic scheme of health risk assessment is the use of certain models of dose-response relationship evaluation, in particular: linear model; linear-exponential model; threshold model and a model of individual action thresholds are determined. World and domestic experiences of their use, depending on the type of problems and the software tools of their calculation were investigated.

Keywords: environmental safety, health risk, potential risk, assessment of "dose-response" dependency. 